\title{
The effects of fat distribution and some adipokines on insulin resistance in subjects with prediabetes
}

\author{
Wpływ dystrybucji tkanki tłuszczowej oraz wybranych adipokin \\ na insulinooporność w stanie przedcukrzycowym \\ Betül Ekiz Bilir', Sibel Güldiken', Nermin Tunçbilek², Ahmet Muzaffer Demir ${ }^{3}$, Ahmet Polat ${ }^{2}$, Bülent Bilir ${ }^{4}$ \\ ${ }^{1}$ Trakya University, Medical Faculty, Internal Medicine Department, Endocrinology and Metabolic Diseases Division, Edirne, Turkey \\ ${ }^{2}$ Trakya University, Medical Faculty, Radiology Department, Edirne, Turkey \\ ${ }^{3}$ Trakya University, Medical Faculty, Internal Medicine Department, Haematology Division, Edirne, Turkey \\ ${ }^{4}$ Edirne State Hospital, Internal Medicine Department, Edirne, Turkey
}

\begin{abstract}
Introduction: The risk of developing insulin resistance and metabolic syndrome is particularly high in central obesity. In this study we evaluated the effects of fat distribution and some adipokines on insulin resistance in prediabetic patients.

Material and methods: Eighty-seven age- and sex-matched patients were divided into three groups according to their 75-gram oral glucose tolerance test results as follows: impaired fasting glucose group, impaired glucose tolerance group, and normal glucose tolerance group. Fasting insulin levels were measured. Homeostatic model assessment of insulin resistance was calculated. Body fat mass measurements were assessed by bioelectric impedance analyser and abdominal fat thicknesses (subcutaneous, visceral, and preperitoneal) by ultrasonography. The fasting serum levels of several adipokines [adiponectin, leptin, resistin, vaspin, visfatin, retinol-binding protein-4 (RBP-4), tumour necrosis factor- $\alpha$ (TNF- $\alpha)$ ] were measured by ELISA method.

Results: The mean body mass index, fat mass measurements, and abdominal fat thicknesses of the groups were similar. There were no differences between groups in terms of the mean fasting insulin, vaspin, RBP-4, leptin, resistin, and TNF- $\alpha$. In comparison of the prediabetic and normal groups, the levels of adiponectin $(p<0.001)$ and visfatin $(p<0.001)$ were lower in the prediabetic group. Furthermore, we found that high body mass index $(\mathrm{p}<0.01)$ and fat mass $(\mathrm{p}<0.01)$ and low adiponectin $(\mathrm{p}<0.05)$ levels have roles in the development of insulin resistance in the prediabetic group.

Conclusions: We suggested that in the prediabetic period not only obesity but also decreased adiponectin levels play some role in the pathogenesis of insulin resistance. (Endokrynol Pol 2016; 67 (3): 277-282)
\end{abstract}

Key words: insulin resistance; adipokine; fat distribution; diabetes mellitus

\begin{abstract}
Streszczenie
Wstęp: Ryzyko rozwoju insulinooporności i zespołu metabolicznego zwiększa się zwłaszcza u osób z otyłością centralną. W niniejszym badaniu oceniono wpływ dystrybucji tkanki tłuszczowej i wybranych adipokin na insulinooporność u osób ze stanem przedcukrzycowym. Materiał i metody: Osiemdziesięciu siedmiu chorych dobranych pod względem wieku I płci podzielono na 3 grupy w zależności od wyniku testu doustnego obciążenia $75 \mathrm{~g}$ glukozy: osoby z nieprawidłową glikemią na czczo, osoby z nieprawidłową tolerancją glukozy i osoby z prawidłową tolerancją glukozy. Zmierzono stężenie insulin na czczo. Do oszacowania insulinooporności zastosowano model homeostazy. Masę tkanki tłuszczowej oceniono za pomocą analizatora bioimpedancji elektrycznej, a grubość brzusznej tkanki tłuszczowej (podskórnej, trzewnej i przedotrzewnowej) zmierzono metodą ultrasonograficzną. Stężenie na czczo w surowicy kilku adipokin (adiponektyna, leptyna, rezystyna, waspina, wisfatyna, białko wiążące retinol-4 [RBP-4], czynnik martwicy nowotworów $\alpha$ [TNF- $\alpha$ ]) zmierzono, stosując metodę ELISA.

Wyniki: Średni wskaźnik masy ciała, masa tkanki tłuszczowej I grubość brzusznej tkanki tłuszczowej były podobne we wszystkich grupach. Nie stwierdzono różnic między grupami pod względem średniego stężenia insuliny na czczo ani stężeń waspiny, RBP-4, leptyny, rezystyny i TNF- $\alpha$. W porównaniu grup ze stanem cukrzycowym i grupy z prawidłową tolerancją glukozy wykazano, że stężenia adiponektyny $(\mathrm{p}<0,001)$ i wisfatyny $(\mathrm{p}<0,001)$ były niższe u osób ze stanem przedcukrzycowym. Ponadto stwierdzono, że wysoki wskaźnik masy ciała $(\mathrm{p}<0,01)$ i duża masa tkanki tłuszczowej $(\mathrm{p}<0,01)$ oraz niskie stężenie adiponektyny $(\mathrm{p}<0,05)$ przyczyniają się do rozwoju insulinooporności u osób ze stanem przedcukrzycowym.

Wnioski: Autorzy sugerują, że nie tylko otyłość, ale również obniżenie stężenia adiponektyny odgrywają pewną rolę w patogenezie insulinooporności w okresie przedcukrzycowym. (Endokrynol Pol 2016; 67 (3): 277-282)
\end{abstract}

Słowa kluczowe: insulinooporność; adipokina; dystrybucja tkanki tłuszczowej; cukrzyca 


\section{Introduction}

It is well known that obesity is an important risk factor for the development of insulin resistance (IR), diabetes mellitus (DM), and cardiovascular diseases. The pathophysiological relationship between obesity and IR is based on not only the degree of obesity but also on the distribution of the fat tissue.

Adipose tissue is a multi-factorial endocrine organ secreting some paracrine and endocrine factors known as adipokines. While some of these adipokines play an important role in the development and progression of IR, such as tumour necrosis factor- $\alpha$ and resistin, some others improve insulin sensitivity, such as adiponectin.

The prediabetic stage comprises impaired fasting glucose (IFG) and impaired glucose tolerance (IGT) terms [1]. The importance of prediabetes comes from the fact that subjects with prediabetes have an increased risk of developing overt Type 2 DM.

We aimed to evaluate the serum levels of some adipokines, body fat distribution, and their relationship with IR in prediabetic subjects.

\section{Material and methods}

\section{Subjects}

In total 87 subjects were included in this study. The subjects who were under treatment with any drugs affecting glucose metabolism (metformin, oral contraceptive drugs, beta-blockers, glucocorticoids, etc.) or were diagnosed with DM, chronic renal failure, hepatic dysfunction, thyroid dysfunction, Cushing's syndrome, any malignancy, or pregnant women were excluded from the study. The subjects were divided into three groups according to their 75-gram oral glucose tolerance test (OGTT) results [1]. 1) IFG group $(n=27) ; 2)$ IGT group ( $\mathrm{n}=36)$; 3 ) healthy subjects with normal glucose metabolism as control group $(n=24)$. The local ethics committee approved the study design and the study was performed in accordance with the ethical standards as laid down in the 2008 amendment of the Declaration of Helsinki. Written informed consent was given by each of the participants.

Weight, body fat mass, fat-free lean mass, and total fat percentages were determined in subjects using a foot-to-foot bioelectric impedance analyser TBF-300 TANITA (Germany) digital scale. Height was measured by a standard tape measure, and body mass index (BMI) was calculated as $\mathrm{kg} / \mathrm{m}^{2}$. Waist circumference was measured by a standard tape measure after expirium as the widest circumference at the level of the right anterior superior iliac spine, parallel to the floor.

\section{Blood Sampling and Assay Methods}

OGTT was done with 75-gram standard anhydrous glucose. The glucose was ingested in $300 \mathrm{ml}$ of water after overnight fasting. Blood samples were drawn initially and two hours after ingestion. Plasma fasting glucose, serum total cholesterol, high density lipoprotein-cholesterol (HDL-C), low density lipoprotein-cholesterol (LDL-C), and triglyceride levels were determined by spectrophotometry method (Advia 1800 Clinical Chemistry System Siemens, USA). The fasting serum insulin levels were assessed by chemiluminescence method (Beckman-Coulter Inc., USA). Homeostatic model assessment of IR (HOMA-IR) was calculated by the formula:

$$
\text { glucose }[\mathrm{mg} / \mathrm{dL}] \times \text { insulin }[\mathrm{m} \mathrm{IU} / \mathrm{mL}] / 405 \text {. }
$$

After centrifugation, blood samples were stored at $-85^{\circ} \mathrm{C}$ until analysis. The fasting serum levels of the adiponectin, retinol-binding protein 4 (RBP-4), tumour necrosis factor- $\alpha$ (TNF- $\alpha$ ), leptin, resistin (AssayMax, Assaypro, USA), vaspin, and visfatin (RayBiotech Inc., USA) were determined by ELISA method.

\section{Ultrasonography}

Abdominal fat distributions were assessed by the same radiologist with a Esaote S.P.A-Italia MyLab 60 ultrasonography machine while the patient was holding his/her breath. Subcutaneous fat (SF) thickness was assessed by 12-MHz linear probe, and visceral fat (VF) and preperitoneal fat $(\mathrm{PF})$ thicknesses were assessed by 5-MHz convex probe.

\section{Statistical analyses}

All statistical analyses were performed using SPSS 17.0 software for Windows. The normality of the distribution of all variables was assessed by the KolmogorovSmirnov test. The comparisons between groups were analyzed by $\chi^{2}$, ANOVA and Kruskal-Wallis test. Pearson's and Spearman's rank correlation coefficients were used to quantify the relations between the variables. $\mathrm{P}<0.05$ was regarded as statistically significant.

\section{Results}

The demographic, anthropometric, and laboratory data of all groups are shown in Table I and II. There were no statistically significant differences between groups in terms of age, gender, BMI, the mean levels of total fat mass, total fat percentages, and fat thicknesses (SF, VF, PF).

The mean levels of waist circumference and HOMAIR in the IGT group were significantly higher than 
Table I. The anthropometric measurements, biochemical and ultrasonographic results of the groups Tabela I. Wyniki pomiarów antropometrycznych, biochemicznych i ultrasonograficznych w poszczególnych grupach

\begin{tabular}{|c|c|c|c|}
\hline & IFG group ( $n=27$ ) & IGT group $(n=36)$ & Control group $(n=24)$ \\
\hline Gender (F/M) & $14 / 13$ & $26 / 10$ & $16 / 8$ \\
\hline Age (year) & $49 \pm 12.73$ & $51.7 \pm 13.1$ & $44.4 \pm 10.3$ \\
\hline $\mathrm{BMI}\left[\mathrm{kg} / \mathrm{m}^{2}\right]$ & $27.7 \pm 4.1$ & $29.7 \pm 3.5$ & $27.4 \pm 5$ \\
\hline Waist circumference [cm] & $100.8 \pm 9.5$ & $104.3 \pm 8.1^{\mathrm{a}}$ & $97.8 \pm 12$ \\
\hline Fasting glucose $[\mathrm{mmol} / \mathrm{L}]$ & $6.0 \pm 0.3^{b}$ & $5.8 \pm 0.5^{c}$ & $4.9 \pm 0.3$ \\
\hline OGTT $2^{\text {nd }}$ hour glucose $[\mathrm{mmol} / \mathrm{L}]$ & $6.2 \pm 1.2^{\mathrm{d}}$ & $8.8 \pm 0.8^{c}$ & $5.53 \pm 1.39$ \\
\hline Fasting serum insulin [pmol/L] & $59.7 \pm 26.3$ & $77 \pm 40.9$ & $57.6 \pm 43.7$ \\
\hline HOMA-IR & $2.33 \pm 1.1$ & $2.85 \pm 1.4^{\mathrm{a}}$ & $1.85 \pm 1.4$ \\
\hline Total cholesterol [mmol/L] & $5.0 \pm 0.8$ & $5.2 \pm 0.8$ & $5.4 \pm 1.2$ \\
\hline $\mathrm{HDL}-\mathrm{C}[\mathrm{mmol} / \mathrm{L}]$ & $1.1 \pm 0.3$ & $1.1 \pm 0.2$ & $1.3 \pm 0.3$ \\
\hline LDL-C [mmol/L] & $3.2 \pm 0.7$ & $3.4 \pm 0.8$ & $3.6 \pm 1.1$ \\
\hline Triglyceride $[\mathrm{mmol} / \mathrm{L}]$ & $1.4 \pm 0.8$ & $1.8 \pm 1.5$ & $1.4 \pm 0.6$ \\
\hline Adiponectin $[\mu \mathrm{g} / \mathrm{mL}]$ & $8.5 \pm 5.8^{b}$ & $12.1 \pm 8.8^{\mathrm{e}}$ & $25.7 \pm 22.4$ \\
\hline Vaspin $[\mathrm{ng} / \mathrm{mL}]$ & $154.3 \pm 640.5$ & $33.3 \pm 115.8$ & $61.7 \pm 176.3$ \\
\hline Visfatin [ng/mL] & $886 \pm 95^{f}$ & $847 \pm 96^{c}$ & $946 \pm 68$ \\
\hline RBP-4 [ng/mL] & $37.03 \pm 6.8$ & $34.3 \pm 7.04$ & $39.01 \pm 7.97$ \\
\hline Leptin $[\mathrm{ng} / \mathrm{mL}]$ & $2.5 \pm 1.6$ & $3.2 \pm 2.9$ & $5.8 \pm 9.7$ \\
\hline Resistin [ng/mL] & $2.4 \pm 0.9$ & $2.8 \pm 1.6$ & $3.2 \pm 1.5$ \\
\hline TNF- $\alpha[\mathrm{ng} / \mathrm{mL}]$ & $0.028 \pm 0.017$ & $0.024 \pm 0.016$ & $0.023 \pm 0.004$ \\
\hline Total fat (\%) & $29.3 \pm 7.9$ & $34 \pm 6.6$ & $29.4 \pm 9.5$ \\
\hline Total fat mass $[\mathrm{kg}]$ & $22 \pm 7.6$ & $26.3 \pm 6.7$ & $22.3 \pm 9.2$ \\
\hline Subcutaneous fat thickness $[\mathrm{mm}]$ & $17.3 \pm 5.5$ & $18.4 \pm 6.2$ & $17.7 \pm 5.8$ \\
\hline Visceral fat thickness [mm] & $47.6 \pm 18.3$ & $57.6 \pm 24.9$ & $46.1 \pm 21.2$ \\
\hline Preperitoneal fat thickness [mm] & $14 \pm 9.2$ & $14.5 \pm 8.3$ & $12.7 \pm 5.7$ \\
\hline
\end{tabular}

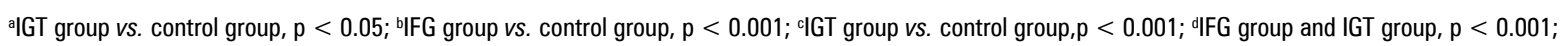
eIGT group vs. control groups, $\mathrm{p}<0.01$; ${ }^{\mathrm{fIFG}}$ group and control group, $\mathrm{p}<0.05$

in the control group $(p<0.05, p<0.05)$ whereas no significant differences were detected in serum insulin and lipid parameters among groups. When the groups were compared statistically, no difference was observed in the serum levels of adipokines, except adiponectin and visfatin. Mean adiponectin and visfatin levels of both IFG and IGT groups were lower than the control group (p: for adiponectin $<0.001$ and $<0.01$; for visfatin $<0.05$ and $<0.001$, respectively), but no difference was found between the IFG and IGT groups. In the prediabetic group there were positive correlations between HOMA-IR and BMI $(\mathrm{p}<0.01)$, waist circumference $(p<0.05)$, second hour glucose level in OGTT $(p<0.05)$, body fat percentage $(p<0.05)$, total fat mass $(p<0.01)$, and visceral fat thickness $(p=0.01)$. In contrast, there was a negative correlation between HOMA-IR and adiponectin levels $(\mathrm{p}<0.05)$ (Table III).

\section{Discussion}

Prediabetes is a state indicating a relatively high risk for future development of DM [1]. In a study examining the prevalence of prediabetes and diabetes in a Turkish adult population, the crude prevalence of prediabetes was $30.8 \%$ (isolated-IFG $14.7 \%$, isolated-IGT $7.9 \%$, and combined $8.2 \%$ ) [2]. In isolated IFG, hepatic IR and insufficiently suppressed endogenous glucose production are the main pathophysiological phenomena; however, in isolated IGT increased peripheral IR and decreased total body glucose disposal are the main problems.

Adipokines are a cytokine group that are released from adipocytes. Studies to uncover their roles on IR pathogenesis give conflicting results. In this study, we aimed to evaluate the effects of some adipokines and body fat distribution on IR in prediabetic patients. 
Table II. The anthropometric measurements, biochemical and ultrasonographic results of the prediabetes group as a whole and the control group

Tabela II. Wyniki pomiarów antropometrycznych, biochemicznych i ultrasonograficznych w potączonej grupie obejmującej wszystkie osoby ze stanem przedcukrzycowym i w grupie kontrolnej

\begin{tabular}{|c|c|c|c|}
\hline & Prediabetes group $(n=63)$ & Control group $(n=24)$ & $\mathbf{P}$ \\
\hline Gender (F/M) & $40 / 23$ & $16 / 8$ & $\mathrm{Ns}^{*}$ \\
\hline Age (year) & $50.6 \pm 12.9$ & $44.4 \pm 10.3$ & Ns \\
\hline $\mathrm{BMI}\left[\mathrm{kg} / \mathrm{m}^{2}\right]$ & $28.8 \pm 3.9$ & $27.4 \pm 5$ & Ns \\
\hline Waist circumference [cm] & $102.8 \pm 8.8$ & $97.8 \pm 12.5$ & Ns \\
\hline Fasting glucose [mmol/L] & $5.9 \pm 0.5$ & $4.9 \pm 0.3$ & $<0.001$ \\
\hline OGTT 2ndhour glucose [mmol/L] & $7.7 \pm 1.6$ & $5.5 \pm 1.3$ & $<0.001$ \\
\hline Fasting serum insulin [pmol/L] & $70.1 \pm 36.1$ & $57.6 \pm 43.7$ & Ns \\
\hline HOMA-IR & $2.63 \pm 1.35$ & $1.85 \pm 1.41$ & $<0.05$ \\
\hline Total cholesterol [mmol/L] & $5.2 \pm 0.8$ & $5.4 \pm 1.2$ & Ns \\
\hline $\mathrm{HDL}-\mathrm{C}[\mathrm{mmol} / \mathrm{L}]$ & $1.1 \pm 0.2$ & $1.3 \pm 0.3$ & Ns \\
\hline LDL-C [mmol/L] & $3.3 \pm 0.7$ & $3.6 \pm 1.1$ & Ns \\
\hline Triglyceride [mmol/L] & $1.6 \pm 1.3$ & $1.4 \pm 0.6$ & Ns \\
\hline Adiponectin $[\mu \mathrm{g} / \mathrm{mL}]$ & $10.6 \pm 7.8$ & $25.7 \pm 22.4$ & $<0.001$ \\
\hline Vaspin $[\mathrm{ng} / \mathrm{mL}]$ & $86.6 \pm 433.5$ & $61.7 \pm 176.3$ & Ns \\
\hline Visfatin $[\mathrm{ng} / \mathrm{mL}]$ & $864 \pm 96$ & $946 \pm 68$ & $<0.001$ \\
\hline RBP-4 [ng/mL] & $35.57 \pm 7.0$ & $39.01 \pm 7.97$ & Ns \\
\hline Leptin [ng/mL] & $2.97 \pm 2.52$ & $5.8 \pm 9.7$ & Ns \\
\hline Resistin [ng/mL] & $2.6 \pm 1.3$ & $3.2 \pm 1.5$ & Ns \\
\hline TNF- $\alpha[\mathrm{ng} / \mathrm{mL}]$ & $0.026 \pm 0.016$ & $0.023 \pm 0.004$ & Ns \\
\hline Total fat (\%) & $32 \pm 7.5$ & $29.4 \pm 9.5$ & Ns \\
\hline Total fat mass [kg] & $24.5 \pm 7.4$ & $22.3 \pm 9.2$ & Ns \\
\hline Subcutaneous fat thickness $[\mathrm{mm}]$ & $17.9 \pm 5.9$ & $17.7 \pm 5.8$ & Ns \\
\hline Visceral fat thickness [mm] & $53.3 \pm 22.7$ & $46.1 \pm 21.2$ & Ns \\
\hline Preperitoneal fat thickness [mm] & $14.3 \pm 8.6$ & $12.7 \pm 5.7$ & Ns \\
\hline
\end{tabular}

Table III. The associations between clinical parameters and HOMA-IR in patients with prediabetes

Tabela III. Zależności między parametrami klinicznymi awskaźnikiem HOMA-IRu osóbze stanem przedcukrzycowym

\begin{tabular}{lcc}
\hline & $\mathbf{r}$ & $\mathbf{P}$ \\
\hline Body mass index $\left[\mathrm{kg} / \mathrm{m}^{2}\right]$ & 0.367 & $<0.01$ \\
\hline Waist circumference $[\mathrm{cm}]$ & 0.361 & $<0.05$ \\
\hline OGTT $2^{\text {nd }}$ hour glucose $[\mathrm{mg} / \mathrm{dL}]$ & 0.282 & $<0.05$ \\
\hline Total fat percentage $(\%)$ & 0.308 & $<0.05$ \\
\hline Total fat mass $[\mathrm{kg}]$ & 0.411 & $<0.01$ \\
\hline Visceral fat thickness $[\mathrm{cm}]$ & 0.395 & 0.01 \\
\hline Adiponectin $[\mu \mathrm{g} / \mathrm{mL}]$ & -0.322 & $<0.05$ \\
\hline
\end{tabular}

As expected, the IR of our prediabetic patients was higher than that of the control group. Our data indicated that IR increased in parallel to the waist circum- ferences from the normal glucose tolerance group to IFG and then to IGT groups. The fact that abdominal obesity has a positive correlation with the IR has been known for a long time. So the result obtained in our study is consistent with earlier findings [3].

It is known that metabolic problems are more prevalent in patients with increased visceral fat mass. Furthermore, visceral fat tissue is an important source of adipokines predominantly increasing IR.

In our study, we did not find any difference between prediabetic patients and normal glucose metabolism group in terms of BMI, fat percentages and fat distributions. This result might be due to our small study cohort.

In our study we suggested that decreased adiponectin levels might have some role in the early stages of impaired glucose metabolism. Furthermore, we found that in the prediabetic stage, decrements in adiponectin levels and increments in fat mass, especially the visceral 
one, have some role in the development of IR, which has a major role in DM pathogenesis.

In the follow-up of 341 women, those with incident diabetes had lower basal serum adiponectin levels in the normal glucose tolerance, IFG, and IGT stages compared to those who did not develop DM during 5.5 years of follow-up [4]. As a result, low adiponectin level was concluded as a predictor of future diabetes and an indicator of the IR. In our study adiponectin levels were also lower in the insulin resistant groups.

Visfatin was first introduced by Fukuhara et al. in their mice and human cell culture study [5] as a novel insulinomimetic adipokine. But recently visfatin was shown as a proinflammatory adipokine causing systemic IR and dyslipidaemia [6]. So the role of visfatin in human pathophysiology is pending clearance because many of the studies on the effects of visfatin are not in accordance with each other $[7,8]$.

There are significant differences in immunoassays of visfatin in regard to the treatment and type of samples. Freeze-thaw cycles and different sample additives have considerable influence on the measurement of visfatin concentrations [9]. Also, Körner et al. revealed the difference between some commercially available immunoassays in terms of specificity and sensitivity of visfatin detection in human serum and plasma [10]. Our study results showed that visfatin levels were lower in the prediabetic group than in the control group and visfatin was inversely proportional to IR. In a recent study, visfatin levels in obese patients with glucose metabolism disorders were found to be lower than obese patients without glucose metabolism disorders, but they did not reach statistical significance (as our study results did) [11]. On the other hand, our results are incompatible with the meta-analysis reported by Chang et al. [8]. This difference in the results might be due to our small sample size or the qualitative/quantitative detection differences of visfatin by immunoassays.

Resistin is also a controversial adipokine in terms of IR. Overexpression of resistin in human hepatocytes induced IR by blocking two insulin signal transduction pathways of PI-3K/Akt and of CAP/c-cbl [12]. In a study comparing plasma resistin levels of lean-insulin sensitive, lean-insulin resistant, and obese-insulin resistant cases, any statistically significant differences between groups or correlation of resistin to insulin sensitivity and intra-abdominal fat tissue were not found [13]. In the present study, also, we did not find any difference between groups with different insulin sensitivity status.

There are also controversial results regarding the RBP4-IR relationship. In the study of Cho et al. [14] RBP4 levels of normal glucose-tolerant subjects were found to be significantly lower than IGT and type 2 diabetic patients. In another study [15] RBP4 levels when corrected with regard to age and gender were not found to be in association with IR in obese patients. As in the previously mentioned study, in our study no difference was found between groups in terms of RBP4 levels. Some factors might be effective in this result. It is known that serum RBP4 levels are affected by plasma transthyretin and retinol levels, but we were not able to measure these levels due to financial limitations. Furthermore, the gold standard method of RBP4 measurement is quantitative western blotting [16], but in our study ELISA was used. This result might be caused by this methodological difference.

The correlation of leptin levels with IR has been studied in many reports [17-19]. In some of them leptin levels were positively related with IR [17-18], but in others no statistical significances were reached [19]. In the present study, we did not reach any difference in leptin levels between groups. Wauters et al. [20] supposed that the main determinants for leptin levels in diabetics and healthy subjects were fat mass and gender. In our study, there were no differences between groups in terms of gender and fat mass parameters. So the indifference in leptin levels between groups might be due to the indifferences in these main determinants or it might be due to our small sample size.

In our study, serum TNF- $\alpha$ concentrations were extremely low and were not statistically different between groups. It was also not correlated with HOMA-IR values, as in the results of Bruun et al. [21]. It is known that TNF- $\alpha$ acts as an autocrine-paracrine basis, not an endocrine basis. So, the indifference between the groups might be related to the measurement of TNF- $\alpha$ in the serum, not at the tissue level, which is the real indicator of its effect on the IR.

von Loeffelholz et al. [22] found no correlation of HOMA-IR with circulating vaspin in non-diabetic cases. Our study was in accordance with this finding also by the lack of correlation between HOMA-IR and vaspin levels.

In the current study, the parameter with the strongest correlation with HOMA-IR was found to be visceral fat thickness. This result supports the well-known fact that visceral fat tissue is a powerful factor responsible for IR and even the development of type 2 DM [23].

There are some limitations of the present study, which might affect our results. Due to its easiness and low cost, in the measurement of IR we used HOMA-IR instead of the gold standard technique - hyperinsulinaemic-euglycaemic clamp test. So some limitations to the study may be borne from this method difference. Moreover, standardisation of the ultrasonographic measurements is very difficult due to the lack of a common probe localisation point for fat thicknesses, variability during respiratory cycles, and low probability of 
reproducibility. Because of ethical issues regarding the radiation exposure during computerised tomography imaging and easiness and low cost of US, although CT is more sensitive than US for the measurement of abdominal fat thicknesses, we used US. So the power of the relationship between fat thicknesses and HOMA-IR may decrease due to this methodological difference.

The fact that serum levels of the adipokines may not always reflect their exact tissue levels might be responsible for the lack of correlation between HOMA-IR and some adipokines in our study. Consequently, if we could take fat tissue biopsies for the measurement of adipokines instead of their serum levels, the correlation of adipokines with IR could be different.

Our study cohort is very small due to our financial limitations. If this study were based on a wider population, the results of the study might have been different from the present issues.

\section{Conclusions}

In conclusion, our results support the role of visceral adiposity on IR. We suggest that lifestyle modifications to minimise abdominal adiposity must begin with the diagnosis of prediabetes to slow the progression rate to overt diabetes mellitus.

\section{References}

1. Genuth S, Alberti KG, Bennett P et al. Expert Committee on the Diagnosis and Classification of Diabetes Mellitus. Follow-up report on the diagnosis of diabetes mellitus. Diabetes Care 2003; 26: 3160-3167. doi: 10.2337/diacare.26.11.3160

2. Satman I, Omer B, Tutuncu Y et al. TURDEP-II Study Group. Twelve-year trends in the prevalence and risk factors of diabetes and prediabetes in Turkish adults. Eur J Epidemiol 2013; 28: 169-180. doi: 10.1007/s10654-013-9771-5.

3. Tanko LB, Bagger YZ, Alexandersen P et al. Peripheral adiposity exhibits an independent dominant antiatherogenic effect in elderly women. Circulation 2003; 107: 1626-1631. doi: 10.1161/01.CIR.0000057974.74060.68.

4. Fagerberg B, Kellis D, Bergström G et al. Adiponectin in relation to insulin sensitivity and insulin secretion in the development of type 2 diabetes: a prospective study in 64-year-old women. J Intern Med 2011; 269: 636-643. doi: 10.1111/j.1365-2796.2010.02336.x.

5. Fukuhara A, Matsuda M, Nishizawa M et al. Visfatin: a protein secreted by visceral fat that mimics the effects of insulin. Science 2005; 307: 426-430. doi: 10.1126/science.1097243.

6. Chang YC, Chang TJ, Lee WJ et al. The relationship of visfatin/pre-Bcell colony-enhancing factor/nicotinamide phosphoribosyltransferase in adipose tissue with inflammation, insulin resistance, and plasma lipids. Metabolism 2010; 59: 93-99. doi: http: //dx.doi.org/10.1016/j. metabol.2009.07.011.

7. Stephens JM, Vidal-Puig AJ. An update on visfatin/pre-B cell colonyenhancing factor, a ubiquitously expressed, illusive cytokine that is regulated in obesity. Curr Opin Lipidol 2006; 17: 128-131. doi: 10.1097/01. mol.0000217893.77746.4b

8. Chang YH, Chang DM, Lin KC et al. Visfatin in overweight/obesity, type 2 diabetes mellitus, insulin resistance, metabolic syndrome and cardiovascular diseases: a meta-analysis and systemic review. Diabetes Metab Res Rev 2011; 27: 515-527. doi: 10.1002/dmrr.1201.

9. Nüsken KD, Nüsken E, Petrasch M et al. Preanalytical influences on the measurement of visfatin by enzyme immuno assay. Clin Chim Acta 2007; 382: 154-156. doi: 10.1016/j.cca.2007.04.004.

10. Körner A, Garten A, Blüher M et al. Molecular characteristics of serum visfatin and differential detection by immunoassays. J Clin Endocrinol Metab 2007; 92: 4783-4791. doi: http: //dx.doi.org/10.1210/jc.2007-1304.

11. Kamińska A, Kopczyńska E, Bieliński Metal. Visfatin concentrations in obese patients in relation to the presence of newly diagnosed glucose metabolism disorders. Endokrynol Pol 2015; 66: 108-113. doi: 10.5603/EP.2015.0016.

12. Sheng CH, Di J, Jin $\mathrm{Y}$ et al. Resistin is expressed in human hepatocytes and induces insulin resistance. Endocrine 2008; 33: 135-143. doi: 10.1007/ s12020-008-9065-y.

13. Utzschneider KM, Carr DB, Tong J et al. Resistin is not associated with insulin sensitivity or the metabolic syndrome in humans. Diabetologia 2005; 48: 2330-2333. doi: 10.1007/s00125-005-1932-y.

14. Cho YM, Youn BS, Lee $\mathrm{H}$ et al. Plasma retinol-binding protein-4 concentrations are elevated in human subjects with impaired glucose tolerance and type 2 diabetes. Diabetes Care 2006; 29: 2457-2461. doi: 10.2337/dc06-0360.

15. Ulgen F, Herder C, Kühn MC et al. Association of serum levels of retinol-binding protein 4 with male sex but not with insulin resistance in obese patients. Arch Physiol Biochem 2010; 116: 57-62. doi: 10.3109/13813451003631421.

16. Graham TE, Wason CJ, Blüher M et al. Short-comings in methodology complicate measurements of serum retinol binding protein (RBP4) in insulin-resistant human subjects. Diabetologia 2007; 50: 814-823. doi: 10.1007/s00125-006-0557-0.

17. Lichnovska R, Gwozdziewiczova S, Chlup R et al. Serum leptin in the development of insulin resistance and other disorders in the metabolic syndrome. Biomed Papers 2005; 149: 119-126.

18. Leon-Cabrera S, Solís-Lozano L, Suárez-Álvarez Ket al. Hyperleptinemia is associated with parameters of low-grade systemic inflammation and metabolic dysfunction in obese human beings. Front Integr Neurosci 2013; 7: 62. doi: 10.3389/fnint.2013.00062.

19. Sharifi F, Yamini M, Esmaeilzadeh A et al. Acylated ghrelin and leptin concentrations in patients with type 2 diabetes mellitus, people with prediabetes and first degree relatives of patients with diabetes, a comparative study. J Diabetes Metab Disord 2013; 12: 51. doi: 10.1186/2251-6581-12-51.

20. Wauters M, Considine RV, Yudkin JS et al. Leptin levels in type 2 diabetes: associations with measures of insulin resistance and insulin secretion. Horm Metab Res 2003; 35: 92-96. doi: 10.3389/fnint.2013.00062.

21. Bruun JM, Verdich C, Toubro $S$ et al. Association between measures of insulin sensitivity and circulating levels of interleukin-8, interleukin-6 and tumor necrosis factor-alpha. Effect of weight loss in obese men. Eur J Endocrinol 2003; 148: 535-542. doi: 10.1530/eje.0.1480535.

22. von Loeffelholz C, Möhlig M, Arafat AM et al. Circulating vaspin is unrelated to insulin sensitivity in a cohort of nondiabetic humans. Eur J Endocrinol 2010; 162: 507-513. doi: 10.1530/EJE-09-0737.

23. Pouliot MC, Desprès JP, Nadeau A et al. Visceral obesity in men. Associations with glucose tolerance, plasma insulin and lipoprotein levels. Diabetes 1992; 41: 826-834. doi: 10.2337/diab.41.7.826. 